DOLLARIZATION AND EXCHANGE RATE FLUCTUATIONS

\author{
Patrick Honohan*
}

\begin{abstract}
Although the worldwide growth in dollarization of bank deposits has recently slowed, it has already reached very high levels in dozens of countries. Building on earlier findings that allowed the main cross-country variations in the share of dollars to be explained in terms of national policies and institutions, this paper turns to analysis of short-run variations, particularly the response of dollarization to exchange rate changes, which is shown to be too small to warrant 'fear of floating' by dollarized economies. But high dollarization is shown to increase the risk of depreciation and even suspension, as indicated by interest rate spreads. While specific policy is needed to deal with the risks associated with dollarization, the underlying causes of unwanted dollarization should also be tackled.
\end{abstract}

An earlier version was presented at the Central Bank of Turkey's $75^{\text {th }}$ Anniversary Conference: "Dollarization: Consequences and Policy Options," Istanbul, December 2006

World Bank Policy Research Working Paper 4172, March 2007

The Policy Research Working Paper Series disseminates the findings of work in progress to encourage the exchange of ideas about development issues. An objective of the series is to get the findings out quickly, even if the presentations are less than fully polished. The papers carry the names of the authors and should be cited accordingly. The findings, interpretations, and conclusions expressed in this paper are entirely those of the authors. They do not necessarily represent the view of the World Bank, its Executive Directors, or the countries they represent. Policy Research Working Papers are available online at http:/lecon.worldbank.org.

\footnotetext{
*The World Bank.

Author email: phonohan@,worldbank.org
} 


\section{DOLLARIZATION AND EXCHANGE RATE FLUCTUATIONS}

\section{Patrick Honohan}

\section{Introduction}

As inflation subsided around the world in the late 1990s, and with a subsequent reduction in the incidence of sharp exchange rate movements, the degree to which depositors at banks were persisting in holding foreign-currency denominated deposits, despite lower inflation, began to attract considerable attention and concern in many central banks. Rather than simply being a reflection of disorderly monetary conditions during high inflation, it began to seem that policymakers were newly facing a persistent phenomenon of dual-currency banking, commonly referred to as dollarization. ${ }^{1}$

It is evident that fluctuations in exchange rates can pose problems in a dual currency system. In turn, a high rate of dollarization of bank deposits could contribute to currency volatility. It is to this dual interaction that the present paper is addressed. We look at the statistical evidence on recent trends in the share dollarization, focusing in particular on the link with actual and expected exchange rate movements.

Policymakers perceive threats from dual currency banking along several exchange-rate related dimensions. First, in the macro sphere, the narrower local currency monetary base could imply an increased elasticity of inflation and/or exchange rate depreciation to monetary shocks, implying a need for greater precision in anti-inflation policy. ${ }^{2}$ Second, the ease with which depositors can switch currency of denomination could also destabilize monetary and exchange rate policy. Third, the national central bank is limited in the extent to which it can provide lender of last resort facilities in foreign currency with the result that systemic liquidity crises could spiral out of control. Fourth, the potential volatility of exchange rates implies considerable market risk for a bank with open foreign currency positions and increases the credit risk of most lending to local borrowers; as a result, a growing share of foreign-currency denominated deposits could both heighten bank solvency risks and reduce the availability of local currency and overall lending to domestic borrowers.

On the other hand, outlawing or restricting the holding of foreign currency deposits is seen as likely to result in an outflow of funds from the banking system as a whole, as depositors found ways of substituting overseas accounts for outlawed domestic ones. This could limit credit availability even further, especially in times of currency crisis.

\footnotetext{
${ }^{1}$ The term "dual currency banking" seems preferable to the more widely used "dollarization", not least because it is euro-denominated holdings that are involved in several countries, and also because the term dollarization is also used to mean the official designation of the US dollar as the national currency, as in Ecuador and some other countries.

${ }^{2}$ It also means that the tax base for seigniorage shrinks.
} 
Not all of these issues can be examined here, though the facts to be presented do throw at least some light on their likely practical importance, and on whether things are getting worse.

The paper begins (Section 1) with a look at overall trends in the share of foreigncurrency-denominated deposits in banking systems around the world, indentifying some hitherto unnoticed features, such as the average slow-down and even reversal in these shares in the last few years, and presents empirical regularities regarding which countries tend to have high ratios and the role of currency depreciation and inflation in generating these high shares.

Section 2 focuses on short-term fluctuations in exchange rates and monetary conditions and seeks to identify the degree to which these impact on dollarization shares both directly and indirectly through expectations and confidence factors. This section casts doubt on exaggerated fears that currency fluctuations result in destabilizing responses in dollarization shares. But it also shows that the reversal in the trend of dollarization shares in 2002-3 can in part be explained by changes in exchange rate trends.

Section 3 turns to the converse relationship, documenting the statistical link between high dollarization shares and interest rates, suggesting an association between dollarization and a heightened fear of exchange rate depreciation and even suspension. Section 4 offers concluding remarks.

\section{The growth and geography of dual-currency banking}

\section{(a) Global trends}

Intensified data-gathering exercises from the late-1990s (e.g. Baliño, Bennet and Borensztein, 1999; Honohan and Shi, 2002; Arteta, 2003; De Nicoló, Honohan and Ize, 2005; Levy-Yeyati, 2006) has greatly increased the number of countries for which some data is available on the share of bank deposits denominated in foreign currency to a total of 133 countries today. (The percentages shown in Figures 1 and 2 and elsewhere in the paper mostly refer to deposit money banks and to the holdings of residents, though it cannot be excluded that in several cases, the concept of residency is somewhat elastic.)

Honohan and Shi (2002) reported an average annual increase of around 1 percentage point per annum for the 1990s, and the plot shown in Figure 1 does not contradict that. Indeed, plotting both mean and median for each year for all countries with data available for that year suggests not only that dollarization rates increased about as quickly during the $1980 \mathrm{~s}$ but that they have continued their increase into the $21^{\text {st }}$ century. At first sight, the upward trend in deposit dollarization even appears to have accelerated since 2001 (Figure 1). This is especially seen in the median, which jumps sharply in 2002. Mean dollarization percentage over all of these countries in 2004 is 33 percent, median 30 percent. 
Deposit dollarization 1985-2004

Unbalanced panel (133 countries)

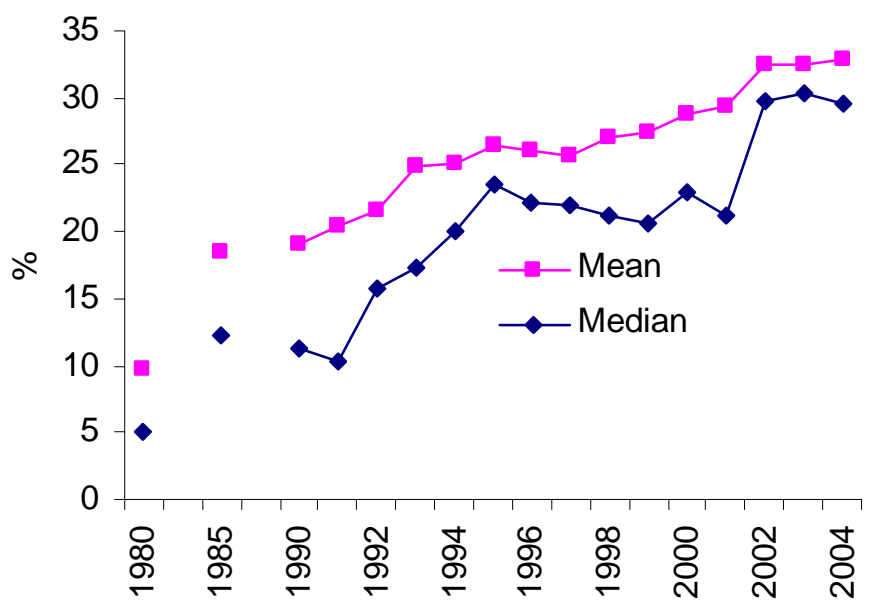

Figure 1: Trends in deposit dollarization 1980-2004.

Data for each based on all available countries for that year.

Source: Based on data in De Nicoló, Honohan and Ize, (2005); Levy-Yeyati (2006)

However, the growth in 2002 is an optical illusion. The number of countries represented in each year changes significantly over time, and it is important to check that there is no sample selection bias in these averages. That becomes evident when we restrict attention to the 76 countries for which data are available for all of the years 1995-2004. For this large sample, both median and mean peak in 2001 and there has been quite a decline since then (Figure 2). The same is true of upper quartile and top decile (Figure 3). Indeed, a prior expectation that the smaller samples of the earlier years would disproportionately represent high dollarization countries does not appear to be confirmed by Figure 2. (Inspection of the countries that drop out of the larger sample because of incomplete data, reveals that the jump in the median of the unbalanced panel after 2001 is partly attributable to the loss from the panel at 2002 of several euro-zone countries which had low dollarization reported, but which drop out of the sample because of the introduction of the euro.) 
Deposit dollarization 1995-2004

Balanced panel 76 countries

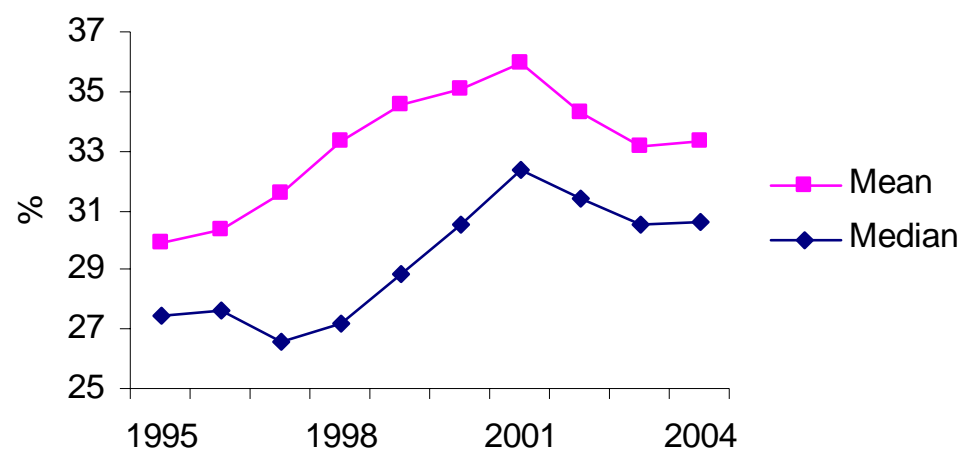

Figure 2: Trends in deposit dollarization 1995-2004.

Data relates to balanced panel comprising all 76 countries for which data is available for all years.

Source: Based on data in De Nicoló, Honohan and Ize, (2005); Levy-Yeyati (2006) “or rable 106xls"

Has the forward march in dollarization ceased, or is this just a pause? One transitory source of a pause could be the fall in the average international value of the US dollar from the first quarter of 2002. Another exceptional event was the forced conversion of the Argentine dollar deposits. These or other short-term factors may have had an effect on dollarization ratios, as will be discussed below.

One way of detecting a change in trend is to fit nonlinear curves to the data. A linear time trend through the unbalanced sample 1990-2004 still gives an estimate of annual increase in dollarization of 0.90 percent per annum (standard error of 0.17 ); with fixed effects, this declines to 0.53 percent per annum (s.e. 0.06). A quadratic time trend shows a sharp slowing of the increase in dollarization (the estimated quadratic peaks at 2004Figure 4). A cubic term in time is also significant: the estimated cubic peaks at 2001. As an alternative, fixed time effects are substituted for the time trend. These clearly show a downturn after 2001 (though the differences from year to year are not statistically significant). 


\section{Deposit dollarization 1995-2004}

Balanced panel 76 countries

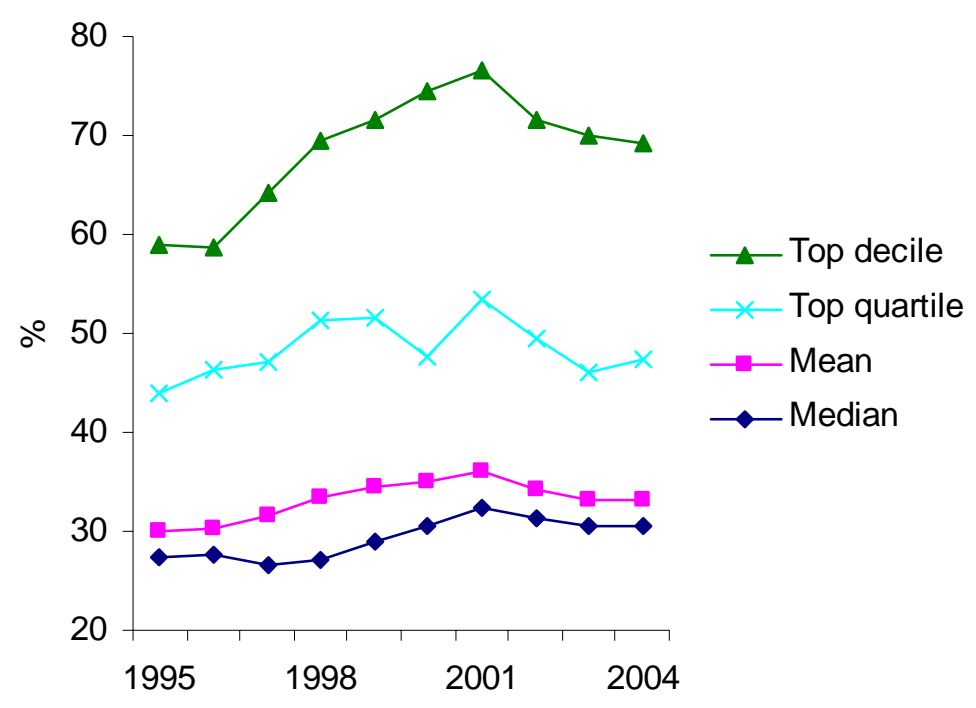

Figure 3: Trends in deposit dollarization 1995-2004.

Data relates to balanced panel comprising all 76 countries for which data is available for all years. Source: Based on data in De Nicoló, Honohan and Ize, (2005); Levy-Yeyati (2006) "or table 106xls"

\section{Estimated time effects}

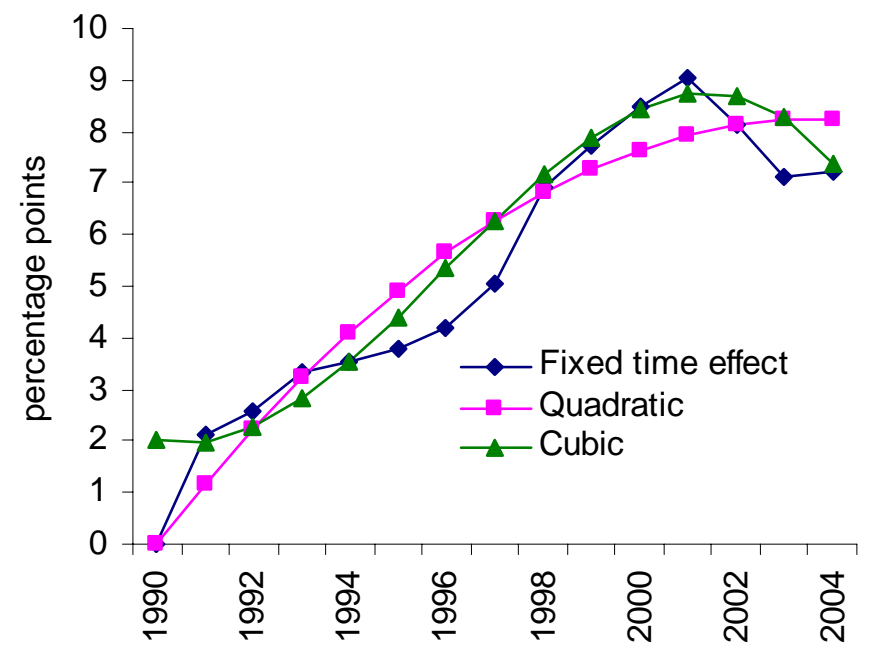

Figure 4: Time effects: estimated coefficients on linear, quadratic or annual dummies.

Based on balanced panel of 76 countries. (See note to Figure 3) 


\section{(b) The geography of dual-currency banking}

The growth in the dollarization of bank deposits - creeping up, as has been mentioned, at about 1 percentage point per annum during the 1990s - remained largely unnoticed when the primary challenge was to bring inflation under control. But now, with few countries displaying high inflation rates, attention has turned to dollarization, which in many cases has in effect been a legacy of their inflationary past. This section asks what kinds of country have high dollarization, defined essentially as having more than half of bank deposits in foreign currency (Table 1). ${ }^{3}$

Extraordinarily high rates of dollarization, in countries such as Cambodia ${ }^{4}$ and Congo, DR, are a fossil remain of earlier episodes of hyperinflation and currency collapse. Such high rates can persist despite a protracted period of currency stability, as witness the case of Lebanon. In some such cases, the fear of another bout of currency weakness or turbulence in the presence of extensive dollarization is a contributing factor to wedding the authorities even more closely to a currency peg, though such pegs can become brittle as in Argentina, 2001.

\footnotetext{
${ }^{3}$ How shall we define high dollarization countries? First, recall that we are dealing with dollarization of the banking system and data is most widely available for deposits (rather than loans). Any banking system with more than half of its deposits denominated in foreign currency can, on a reasonable common-sense criterion, be described as highly dollarized. A roughly equivalent alternative is the top quartile of the 130some countries for which data is available. And these criteria could be applied to the latest year, the average of the latest few years, or the maximum reached since 1990. Actually most of these criteria select roughly the same group of countries. Let us therefore work with all countries that makes the grade on any of these criteria.

${ }^{4}$ Bolivia had the highest ratios before the Cambodia data enters the series. Since then Cambodia has had the highest value in each year, with no sign of decline - indeed the last year is also the highest for Cambodia.
} 


\section{Peak inflation and dollarization}

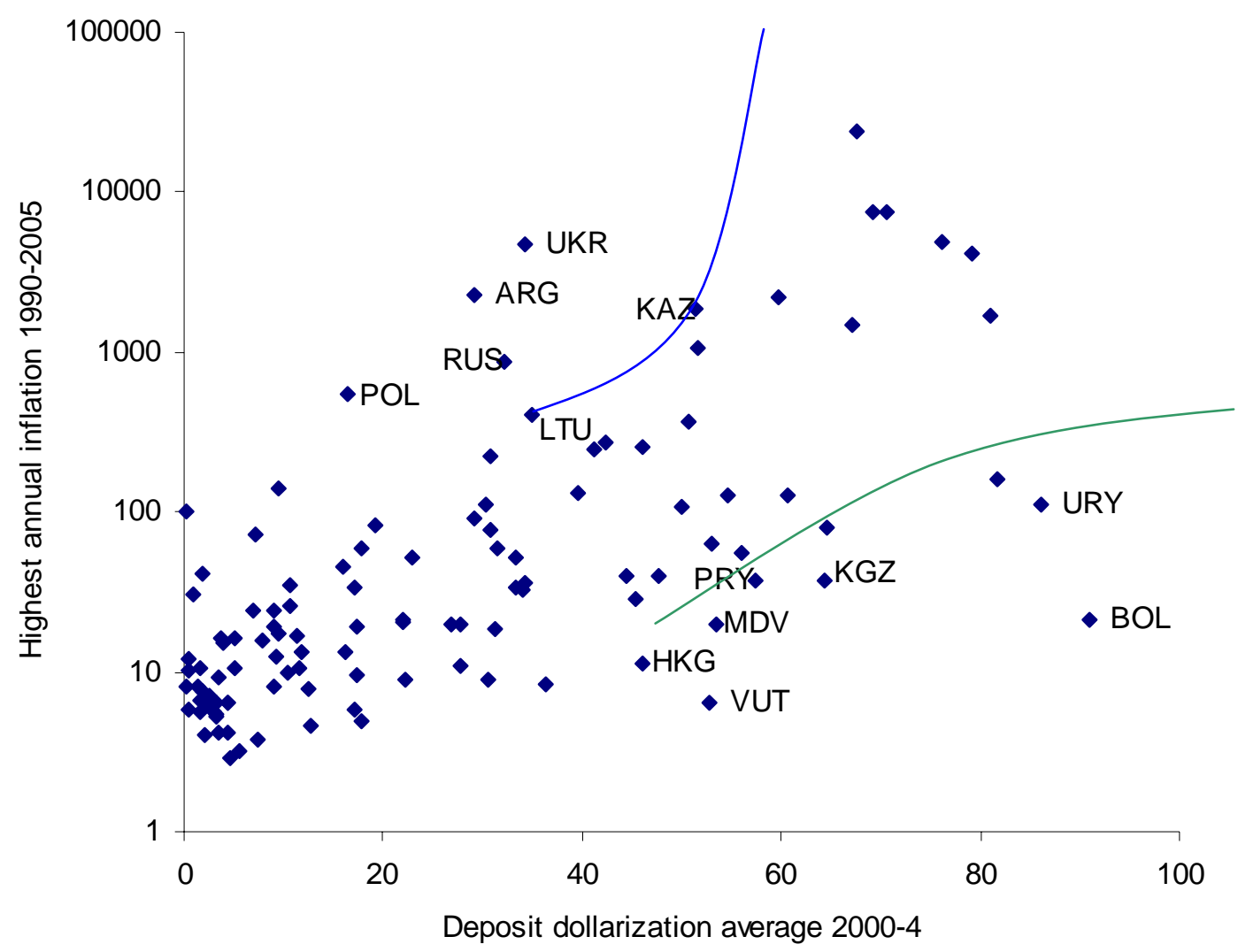

Figure 5: Peak inflation and dollarization

See note to Figure 3

The proposition that a history of high inflation is a key causal factor for dollarization is clearly shown in Figure 5. No country ${ }^{5}$ that has kept inflation below about 35 percent per annum has high dollarization. More generally, the upper curved (green) line suggests the minimum inflation trigger for high dollarization ratios. Bolivia, Paraguay and the Kyrgyz Republic aside, the only countries below this line are offshore financial centers. (Bolivia has a much higher dollarization ratio than predicted by the line, but the chart is drawn for the highest inflation recorded 1990-2005 and Bolivia's hyperinflation was in the mid-1980s; Paraguay also recorded rather higher inflation rates in the 1980s. The case of the Kyrgyz Republic is simpler: the IFS data source for this country starts only in 1996 and so omits the hyperinflation of 1992-93.) Conversely, no country with hyperinflation has managed to escape high dollarization except by regulation. The lower curved (blue) line suggests the threshold. The three or four countries to the left of the line and with peak inflation rates of more than 500 percent per annum all had higher dollarization ratios (above 40 percent in each case) in the 1990s before falling back to the average 2000-4 ratios shown.

\footnotetext{
${ }^{5}$ The offshore center Vanuatu aside.
} 
A large share of foreign currency deposits can also be found in countries which have long been bastions of financial stability. One variant of this is the international, regional or offshore banking center. Many of the countries which offer tax, secrecy and other advantages to offshore depositors end up with a high fraction of foreign currency in the liabilities of their banking systems. Five such countries are among the top three dozen countries in the world for deposit dollarization. ${ }^{6}$ (For some of these countries it is likely that a sizable fraction of even what are treated in the statistics as foreign currency deposits of residents is beneficially owned by non-residents. Such countries need to be treated separately.)

The other variant relates to the growing euro zone (which acquires a $13^{\text {th }}$ member, Slovenia, on January 1,2007) and its fringe of aspirants which have adopted currency board or similar arrangements based on the euro. Their banking and business communities are already adjusting their portfolio behavior on the expectation that these links will be transformed into full euro membership before too long. Five such countries ${ }^{7}$ are among the top three dozen in the world for deposit dollarization (or euroization, as it might better be called in this context).

All of these offshore, regional financial center or euro-convergent countries are maintaining tight pegs in practice, though it is not quite obvious why there should be a necessary or logical link between an exchange rate peg and building up an offshore center.

Of the remaining score of high dollarization countries, only four hold a tight US dollar relationship in practice (we used a standard deviation of annual change in the US dollar exchange rate of not more than 2.25 percent per annum 2000-2005 as the criterion for a tight relationship). So, despite much discussion in the literature (cf. Calvo and Reinhart, 2002) "fear of floating" is not the dominant exchange rate policy of high dollarization countries (other than regional or offshore financial centers); a clear majority choose more flexible regimes.

Thus we have two classes of highly dollarized economies: (a) a mixed bag of countries with a history of high or hyperinflation, many of them now reforming or reformed; and (b) island rocks of financial stability. Lebanon is an interesting hybrid case, combining as it does aspects of both types, given its high inflation during wartime - the Lebanese pound price of US dollars rose 200 fold in the 8 years to 1992 - and its resumed role as a major regional banking center with exceptional monetary depth (M2 is 250 percent of GDP) and a rigid exchange rate for the past decade.

\footnotetext{
${ }^{6}$ Costa Rica, Djibouti, Lebanon, Maldives, Uruguay. The case of Hong Kong — an international financial center - is somewhat similar from this point of view.

${ }^{7}$ Bosnia IH, Bulgaria, Croatia, Lithuania and Macedonia. The data on dollarization in Guinea-Bissau, a euro-linked country since 1997, relates to previous years.
} 
Table 1: High Dollarization Countries

\begin{tabular}{|c|c|c|c|c|c|c|c|}
\hline & 2004 & $\begin{array}{c}\text { Max } \\
1990-2004\end{array}$ & $\begin{array}{l}\text { Average } \\
2000-4\end{array}$ & & 2004 & $\begin{array}{c}\text { Max } \\
1990-2004\end{array}$ & $\begin{array}{c}\text { Average } \\
2000-4\end{array}$ \\
\hline Angola & 71.9 & 85.0 & 79.1 & Lao PDR & 32.5 & 89.6 & 60.6 \\
\hline Argentina & 3.7 & 73.6 & 29.1 & Lebanon & 64.9 & 69.2 & 64.6 \\
\hline Armenia & 78.2 & 81.2 & 76.2 & Liberia & 89.7 & 89.7 & 87.8 \\
\hline Azerbaijan & 79.9 & 84.2 & 81.0 & Lithuania & 25.1 & 62.7 & 35.0 \\
\hline Belarus & 48.0 & 69.4 & 59.7 & Macedonia, FYR & 53.3 & 61.4 & 54.5 \\
\hline Bolivia & 86.7 & 92.6 & 91.0 & Maldives & 61.9 & 61.9 & 53.5 \\
\hline Bosnia and Herzegovina & 48.1 & 88.8 & 53.2 & Moldova & 44.7 & 50.1 & 47.8 \\
\hline Bulgaria & 49.1 & 57.2 & 51.7 & Mozambique & 60.2 & 60.2 & 53.1 \\
\hline Cambodia & 95.7 & 95.7 & 94.7 & Nicaragua & 70.3 & 72.1 & 70.7 \\
\hline China,P.R.:Hong Kong & 47.8 & 59.6 & 46.1 & Paraguay & 50.5 & 66.9 & 57.4 \\
\hline Congo, Dem. Rep. of & 86.0 & 86.0 & 67.7 & Peru & 68.3 & 73.2 & 69.2 \\
\hline Costa Rica & 50.4 & 50.4 & 45.5 & São Tomé \& Príncipe & 47.1 & 51.8 & 48.5 \\
\hline Croatia & 61.6 & 73.8 & 67.2 & Suriname & 56.5 & 56.5 & 50.7 \\
\hline Djibouti & na. & 68.2 & 56.2 & Tajikistan & 66.9 & 72.4 & 65.6 \\
\hline Egypt & 32.7 & 55.6 & 27.7 & Turkey & 42.4 & 58.5 & 49.9 \\
\hline Georgia & 74.3 & 86.1 & 81.8 & Uruguay & 87.6 & 88.8 & 86.2 \\
\hline Guinea-Bissau & na. & 57.9 & & Vanuatu & 45.3 & 79.3 & 52.7 \\
\hline Kazakhstan & 43.0 & 60.0 & 51.5 & Yemen, Republic of & 54.5 & 61.2 & 55.9 \\
\hline Kyrgyz Republic & 59.0 & 66.8 & 64.3 & & & & \\
\hline
\end{tabular}

Shows the percentage of deposits denominated in foreign currency. The criteria used to select high dollarization countries are in footnote 4. Source: Based on data in De Nicoló, Honohan and Ize, (2005); Levy-Yeyati (2006). 


\section{(c) Quantifying the medium-term causal factors}

A country's inflationary history is not the only factor likely to influence concerns about a recurrence of a major macroeconomic collapse. For one thing, weak governmental institutions, for example those inhibiting the government from credible precommitment would be likely to adversely affect confidence in the domestic currency and promote foreign currency holdings. (See De Nicoló, Honohan and Ize, 2005, for a review of the literature in this area.)

Even if there were no great concerns about a significant collapse of monetary policy discipline or of the exchange rate, normal volatility of inflation and exchange rates provide a reason why the optimal deposit portfolio might include dollars. After all, as pointed out by Ize and Levy Yeyati (2003), the volatility of the real value of a dualcurrency portfolio depends on the variance and covariance of inflation and exchange rates. If the mean return on each currency is equal, standard mean-variance portfolio optimization points point to a "warranted" dollarization share $\lambda$ based on the minimum variance portfolio calculated from historic variances and covariances of prices and exchange rates. ${ }^{8}$

Recent attempts to quantify these considerations and to estimate the impact of each on cross-country variation in average dollarization ratios have been reasonably successful. De Nicoló, Honohan and Ize. (2005) used the World Bank's composite indicators of political and institutional development (cf. Kaufman, Kraay and Mastruzzi, 2006) as a measure of governance and a proxy for policy credibility, and supplemented this by a dummy for countries whose legal system is inherited from Napoleonic code - an inheritance which is often thought to offer lower protections to creditors and lead to shallower financial systems (cf. La Porta, López-de-Silanes, Shleifer, and Vishny, 1998; Levine, Loayza and Beck, 2000). The regression equations of De Nicoló, Honohan and Ize (2005) also included the average historic rate of inflation, a dummy for Transition economies and the warranted share from mean-variance considerations $\lambda$. Finally, they included a dummy variable summarizing the restrictiveness of rules on resident holdings of foreign currency deposits onshore in 2000, and based on the IMF's Annual Report on Exchange Arrangements and Exchange Restrictions.

Using these variables measuring institutional quality, regulatory frameworks, and the macroeconomic environment, De Nicoló, Honohan and Ize (2005) were able to explain about half of the cross-country variation in the 75 countries included in their sample. As expected, high inflation and weak institutions increased dollarization shares substantially. For instance an increase of 2 percentage points in the warranted portfolio share $\lambda$ is associated in the regression with an increase in actual dollarization by almost 1 percentage point. Inflation is also found to have a strong effect; a doubling of inflation increasing dollarization by about 5 percentage points. But inflation loses significance when structural and institutional proxies for credibility effects are added in, suggesting

${ }^{8}$ The warranted share $\lambda$ is $\lambda=\frac{V(\pi)+\operatorname{Cov}(\pi, s)}{V(\pi)+V(s)+2 \operatorname{Cov}(\pi, s)}$, where $\pi$ is inflation and $s$ is real depreciation. 
both that credibility effects are important and that credibility (and inflation) have important structural and institutional underlying determinants.

\section{How exchange rate movements influence dollarization in the short run}

Exchange rate depreciation tends to have a short-run effect on dollarization through both direct and indirect mechanisms.

The direct mechanism is clear: even if there is no change in the dollar value of the dollar holdings and none in the local currency value of local currency deposits, nevertheless depreciation will have an effect on the value ratio. This is a mechanical effect, which can easily and quickly be offset by deliberate action by the depositor to rebalance the portfolio, shifting some dollar deposits into local currency.

But the indirect effect may have a longer-lasting impact by affecting the desired currency ratio (dollarization share). Not only may the depreciation result in a revised estimate of the covariances in the definition of $\lambda$ (the theoretical "warranted" rate - see above), but likely more important is the impact on expectations of major future currency movements. The expectation effect could amplify the direct effect if the depreciation causes a revision of expectations about the likely long-term path of the exchange rate. On the other hand, if the depreciation is seen as corrective, undoing a deviation from an unchanged mediumterm equilibrium path, it could reduce fears of future depreciation. This is all conditional on interest rate differentials which could move endogenously to offset any change in desired dollarization ratio.

\section{(a) The mechanical effect}

The nominal quantity of local currency base money, the exchange rate and the relevant interest rates are the major measurable elements in the short-term evolution of dollarization ratios. Writing the dollarization share as $\delta$, the foreign currency value of foreign currency deposits as $f$, the exchange rate (local currency price of foreign exchange) as $e$ and the local currency value of local currency deposits as $c$, we can write:

$$
\delta_{t}=\frac{e_{t} f_{t}}{c_{t}+e_{t} f_{t}} .
$$

If the number of dollars and local currency units held is constant, nevertheless the dollarization ratio $\delta$ will change if exchange rates change. In order to understand what is behind dollarization share changes it is important to be able to isolate the element of the change attributable to this unrebalanced impact valuation effect of exchange rate change.

First, note that the value ratio of foreign to local currency holdings $\left(v_{t} \equiv \frac{e_{t} f_{t}}{c_{t}}=\frac{\delta_{t}}{1-\delta_{t}}\right)$ will change proportionately to the exchange rate (price of foreign exchange) $e$. Figure 6 plots $\Delta \ln v$ against $\Delta \ln e$ for all 1251 one-year changes in the database. The plot shows that numerous changes in the value ratio $v$ have occurred without any change in the 
exchange rate (along the $y$-axis). In addition, there are numerous changes in exchange rates associated with changes in $v$ that are either much larger or much smaller than predicted by the law of proportionality (indicated by the diagonal line). It is clear that this mechanical valuation change is not a dominant element in one-year changes in dollarization.

\section{Exchange rate and \\ dollarization ratios}

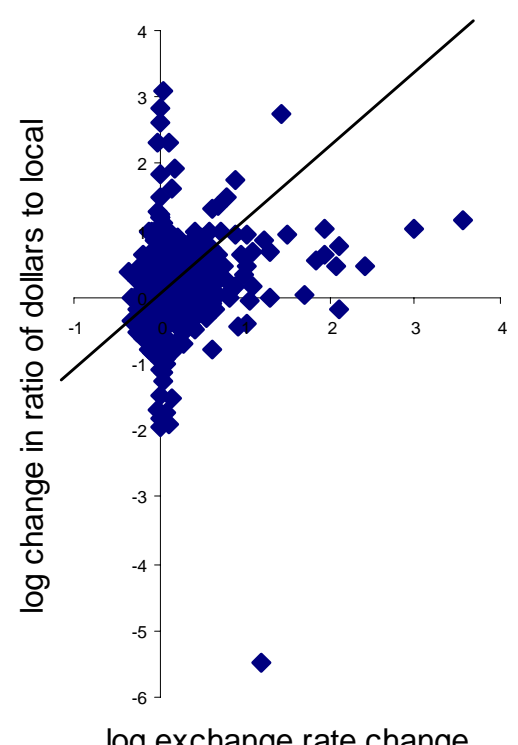

log exchange rate change

Figure 6: Changes in exchange rate and in the ratio of dollar to local currency deposits Source: IFS and as in Fig. 3

In order to derive the relationship between changes in exchange rate and the dollarization share $\delta$ (as distinct from the value ratio $v$ ), we totally differentiate the above definition of $v$ in terms of $\delta$ to suggest the approximation

$$
\Delta v \approx \frac{\Delta \delta}{(1-\delta)^{2}},
$$

And if $f$ and $c$ are constant, then the definition of $v$ in terms of these variables would imply:

$$
\Delta v=v \Delta \log e
$$

Combining these two implies that the impact effect of exchange rate change on dollarization share can be written as:

$$
\Delta \delta \approx(1-\delta) \delta \Delta \log e
$$

Another almost mechanical effect could come from changes in nominal value of the local-currency monetary base, if this is under policy control, whether coming from a monetized government deficit or from open-market operations. An accumulation of local 
currency deposits when neither dollar deposits nor the exchange rate is changing would shift the dollarization share by an amount which can be approximated by:

$$
\Delta \delta \approx(1-\delta) \delta \Delta \log c
$$

This again is an impact effect: depositors could rebalance.

\section{(b) Modeling short-term fluctuations in dollarization}

The other determinants of short-term changes in dollarization would include changes in the desired dollarization share, $\delta^{*}$, and the degree to which rebalancing achieves that preferred dollarization share by the date of observation.

These considerations suggest a simple dynamic model of dollarization in which impact factors include the change in the exchange rate and in the domestic money base, allowing the impact of the exchange rate to be proportional to the calculated impact effects presented above (allowing both for short-term indirect effects and within interval rebalancing), with estimated factors of proportionality $a_{1}$ and $a_{2}$. An error-correction formulation allows deviations from desired dollarization share to be closed over time, with the speed of adjustment measured by the parameter $a_{3}$ :

$$
\Delta \delta_{t}=a_{0}+a_{1}\left(1-\delta_{t}\right) \delta_{t} \Delta \log e_{t}+a_{2}\left(1-\delta_{t}\right) \delta_{t} \Delta \log m_{t}+a_{3}\left(\delta_{t}^{*}-\delta_{t-i}\right)+u_{t}
$$

where $u$ is a random disturbance.

The desired dollarization rate could be modeled as a function of time-varying as well as slow-moving factors as discussed in the previous section. These can be partly captured by time trends and country dummies (fixed effects).

Table 2 shows estimates of such an equation. ${ }^{9}$ In line with the model, exchange rate depreciation is found to increase dollarization share in the short-run, while monetary expansion reduces it, again in the short run. The estimated error-correction process indicates convergence after shocks. Both the estimated impact effects and the errorcorrection coefficient are statistically significant at very demanding levels. ${ }^{10}$

\footnotetext{
${ }^{9}$ Table 1 shows a range of alternative estimates, mostly using fixed country effects to control for national differences in the medium-term equilibrium. The lag $i$ on $\delta$ is set at 2 . Almost one thousand data points for 121 countries are included in the regressions covering the period 1993 to 2004 (earlier data points are lost because of differencing). Regressions 1.1, 1.4 and 1.7 use the full set of data, while the others eliminate some outliers. For regressions 1.2, 1.5 and 1.8 we deleted nine large outliers - greater than 15 percentage points or three times the standard error of regression 1.1-from five countries Argentina, Bosnia IH, Congo DR, Lao PDR and Yemen. For regressions 1.3, 1.6 and 1.9 we deleted 12 further outliers (greater than 10 percentage points) from 10 countries. White-consistent standard errors are reported in regression 1.10 (otherwise equivalent to 1.3). Regression 1.11 shows the result of feasible GLS estimation weighted using residual cross-section variances. Regression 1.12 removes the fixed country effects.

${ }^{10}$ It would be desirable to control for endogeneity by using instrumental variables. Even lagged values of the included variables would help in this regard. However, the large number of cross-sections (countries) relative to time points limits the degrees of freedom and presents technical challenges here which are still being tackled. For similar reasons, allowing the coefficient on the time trend to vary across countries results in a near-singular matrix, as does attempting a Parks estimation (allowing contemporaneous correlation across countries).
} 
Table 2. Dynamic evolution of dollarization

(Dependent Variable: Change in Deposit Dollarization Percentage Share)

\begin{tabular}{|c|c|c|c|c|c|c|c|c|c|c|c|c|}
\hline \multirow{2}{*}{$\begin{array}{ll}\text { Variable } & \text { Equation: } \\
\end{array}$} & \multicolumn{2}{|l|}{1.1} & \multicolumn{2}{|l|}{1.2} & \multicolumn{2}{|l|}{1.3} & \multicolumn{2}{|l|}{1.4} & \multicolumn{2}{|l|}{1.5} & \multicolumn{2}{|l|}{1.6} \\
\hline & Coeff. & $\mathrm{t}$-Stat & Coeff. & $\mathrm{t}$-Stat & Coeff. & t-Stat & Coeff. & $\mathrm{t}$-Stat & Coeff. & t-Stat & Coeff. & t-Stat \\
\hline Constant & country & & country & & country & & country & & country & & country & \\
\hline xchange rate factor & 0.228 & $5.7 * *$ & 0.439 & $14.3 * *$ & 0.546 & $16.6 * *$ & 0.324 & $6.1 * *$ & 0.567 & $14.4 * *$ & 0.567 & $15.4 * *$ \\
\hline Ion & -0.231 & $-5.5 * *$ & -0.244 & $-8.2 * *$ & -0.288 & -8 & -0.197 & & -0.286 & & -0.293 & $-8.5 * *$ \\
\hline tion & -0.287 & $-14.6^{* *}$ & -0.260 & $-16.6^{* *}$ & -0.239 & $-16.3 * *$ & -0.273 & $-13.0 * *$ & -0.245 & $-14.9 * *$ & -0.234 & $-15.0 * *$ \\
\hline terest rate & & & & & & & -0.012 & -0.5 & -0.027 & -1.7 & -0.017 & -1.2 \\
\hline ion & & & & & & & & & & & & \\
\hline & 044 & & 18 & & 23 & & 036 & 0.8 & 0.098 & & 0.117 & 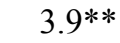 \\
\hline & -0.362 & 2.0 & -0.413 & -14 & -0.417 & & -0.369 & ** & -0.420 & & -0.421 & $0 * *$ \\
\hline Cour & all & & 5 dum & 121 & 15 dum & 1 & all & 21 & $5 \mathrm{dum}$ & 21 & $15 \mathrm{dum}$ & 121 \\
\hline & 0.336 & & 0.502 & & 0.569 & & 0.315 & 21 & 0.504 & 04 & 0.543 & 875 \\
\hline $\mathrm{W}$ & 0.240 & & 0.427 & 2.16 & 0.501 & 2 & 0.211 & 2.07 & 0.427 & 2.20 & 0.470 & 2.21 \\
\hline & 4.67 & $r$ & 3.29 & I S & 2.90 & $\mathrm{LS}$ & 4.50 & LS & 3.18 & LS & 2.90 & LS \\
\hline & 1.7 & & 1.8 & & 1.9 & & 1.10 & & 1.11 & & 1.12 & \\
\hline Variable & oeff. & Stat & Coeff. & Stat & Coeff. & t-Stat & Coeff. & t-Stat & Coeff. & t-Stat & Coeff. & $\mathrm{t}$-Stat \\
\hline & country & & country & & country & & country & & country & & 0.583 & 1. \\
\hline & 318 & & 579 & & 577 & & 0.546 & & 0.498 & & 671 & $18.0^{*}$ \\
\hline & 35 & & 94 & & -0.302 & & -0.288 & & -0.127 & & -0.397 & $-11.9 *$ \\
\hline & -0.253 & $-10.7 * *$ & -0.231 & $-12.9^{* *}$ & -0.218 & $-12.8 * *$ & -0.239 & $-12.4 * *$ & -0.235 & $-17.8^{* *}$ & -0.000 & -0.1 \\
\hline & 0.020 & 0.1 & -0.024 & -1.5 & -0.013 & -0.8 & & & & & & \\
\hline & 054 & & & & 0.042 & & & & & & & \\
\hline & 0.033 & 0 & 108 & & 0.131 & & 123 & & 0.183 & & 0.011 & 0.3 \\
\hline & -0.333 & $-10.1 * *$ & -0.388 & $-12.8 * *$ & -0.379 & $-12.8 * *$ & -0.417 & $-11.3 * *$ & -0.339 & $-12.7 * *$ & -0.079 & $2.9 * *$ \\
\hline tevartios & all & & 5 dum & 121 & 15 dum & 121 & 15 dum & 121 & 15 dum & 121 & $15 \mathrm{dum}$ & 121 \\
\hline$x_{-1}+2$ & 79 & & & & & & 0.569 & 27 & 0.541 & 927 & 0.268 & 927 \\
\hline 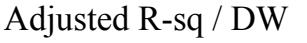 & & 2.00 & & 2.17 & 37 & & 0.501 & & 0.469 & 2.24 & 0.265 & 1.78 \\
\hline SER/Method & 4.49 & LS & 3.06 & LS & 2.77 & LS & 2.90 & White & 2.99 & GLS & 3.52 & LS \\
\hline
\end{tabular}

Notes: Sample: all dates/countries for which data was available 1990-2004, except for equations marked ' 5 dum' in which nine observations from 5 countries were excluded (as outliers): Argentina, 2001, 2002; Armenia 2002, Bosnia IH, 2001; Congo, DR, 2003; Lao PDR, 1999, 2003; Yemen, 1993-95; and those marked 15 'dum,' in which a further twelve outliers (from a further 10 countries) were excluded: Bolivia, 1996; Congo, DR, 2000, 2002; Djibouti, 1998; Malawi, 1998;

Maldives MDV, 2000; Paraguay, 2002; Romania, 1994; Sierra Leone, 2001; Sudan, 1996; Tanzania, 1998; Vanuatu, 2002. Dollarization share $\delta$ is share of foreign currency-denominated deposits in total deposits (source De Nicoló, Honohan and Ize, 2005; Levy Yeyati, 2006); Dependent variable is $100 \Delta \delta$. Exchange rate factor is $\delta(1-\delta) \Delta \ln e$; money base factor is $\delta(1-\delta) \Delta \ln m$ as discussed in the text. Exchange rate $e$ is IFS line ...ae. Money base $m$ is IFS line 14. Deposit interest rate is IFS line 60L. Cumulative inflation is the sum of current year and two lags in CPI inflation calculated from IFS line 64. SER is standard error of regression. Estimation method: LS means that, after transformation to take account of the AR(1) term, estimation is by nonlinear least squares (assuming disturbances are otherwise iid); White means that standard errors in an LS regression were estimated using White's heteroskedasticity-consistent estimator; GLS means that feasible Generalized Least Squares was used with weights based on cross-section residual variances. "country" means that the regression included country fixed effects. Estimates calculated with EViews. ** and * denote coefficients significant at 1\% and 5\% levels respectively. 
The assumption that medium-term equilibrium is for each country constant up to a time trend is not likely to be adequate, considering the major regime changes that have occurred, including the diverse experience of Transition economies, as well as financial and exchange rate crises and changes in national regulations concerning dollarization. In order to reduce the risk that this misspecification is biasing the results (and in the absence of a full annual database of the other relevant explanatory factors), we present results both for the full data set, and for reduced sets generated by removing outliers. Removal of outliers has the effect of increasing the estimated impact of exchange rate changes (from 0.23 to 0.55 ) but even the higher number indicates that the average within year effect of exchange rate changes is less than the theoretical impact on an unrebalanced portfolio (i.e. 1.00). Thus, dollarization shares are not always highly sensitive to exchange rate movements, and in particular that depreciation does not always result in a jump in desired dollarization.

This finding, implying that dollarization does not systematically tend to destabilize a variable exchange rate regime, has clear implications for exchange rate policy.

Taken in conjunction with the error-correction term, the estimated time trend is positive, varying from about 0.15 for the regressions including the full sample through 0.52 in regression (1.3) and as much as 0.78 in the weighted GLS regression (1.11). A quadratic term in time, which could imply an estimated slowdown or reversal, was not significant, implying that - if we remove the outliers - the regressions point to an upward annual trend in dollarization of between $1 / 2$ and $3 / 4$ percentage points per annum. However, the actual downturn in the later years deserves a closer look.

\section{(c) Interpreting the recent slow-down: is it an exchange rate effect?}

Armed with an estimate of how exchange rate movements impact on dollarization in the short-term, we can now revisit the question of whether dollar weakness was a major factor in the apparent average downturn in dollarization rates in 2002-3.

As measured with respect to the DM and euro, the dollar weakness in those years was much larger than previous experience during the sample period 1990-2005 (Figure 7). But the relevant exchange rate for measuring direct impact is the bilateral rate for each currency. Figure 7 shows that median and mean depreciation of the dollar against the countries in our sample were both close to zero in 2002-2004. So the dollar movements of those years cannot have had a sizable direct impact on dollarization. However, it is also clear that the 1990s saw sizable average and median appreciation of the dollar against sample country currencies, whether or not the average is weighted by national dollarization shares. Thus the impact effect of currency movements in each year could have been sizable.

Taking the estimate that about a half of the impact of currency movements would be rebalanced within the year and assuming the remainder would be rebalanced before the next end-year allows us to calculate an adjusted dollarization figure net of short-run exchange rate change impacts, using the formula provided above (Figure 8). Adjusted 
figures could be interpreted as better reflecting underlying trends. This should be thought of as a maximal adjustment, given that it neglects the offsetting impact of simultaneous money base increases which could have contributed to the currency movements. The adjusted average figure is lower in the 1990s, and little different from the unadjusted for 2001 to 2004. The adjusted figures suggest a faster underlying rise in dollarization up to 2001 , and a subsequent fall back that was less severe. Instead of the 2003 figure being lower than that of 1998, the adjusted data suggest a fall back only to somewhere between the levels of 1999 and 2000.

However, the adjustment does not put into question the evidence that there was a break in the growing trend of dollarization around 2001. Although a mechanical exchange rate cause is ruled out by the calculations here presented, the changing fortunes of the dollar could have played a role here, indirectly through an effect on desired dollarization.

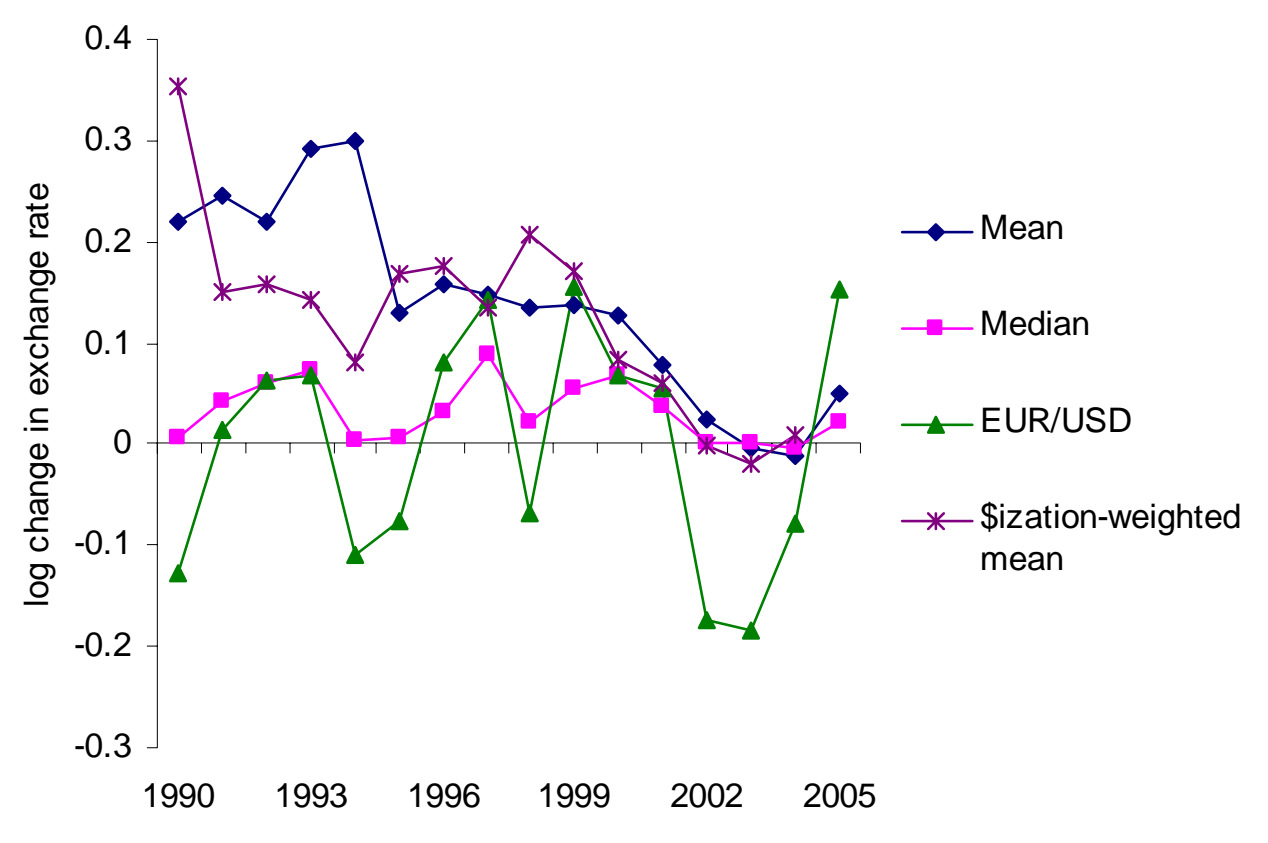

Figure 7. Annual dollar appreciation against currencies in the sample

There are other possible causes for a break in the upward trend of dollarization around 2001. We already mentioned the direct effect of the forced conversion (at an unfavorable rate) of dollar deposits in Argentina. ${ }^{11}$ This certainly lowered the Argentine percentage but might also have had a demonstration effect on behavior elsewhere: dollar deposits not as attractive now. Did that result in a shift to offshore deposits in lieu?

\footnotetext{
${ }^{11}$ Note that measured, on-shore, dollarization is not a comprehensive picture of portfolio preferences. Outlawed in many countries, dollar deposits can show up much less than would be predicted for a country where they are freely permitted. One only has to look at the sharp drop in Argentine dollar-denominated deposits in 2002. It is not that Argentina's monetary authorities had suddenly produced a much more attractive product that displaced dollars in the preferred liquid portfolio of Argentine residents. Far from it; they had just outlawed most holdings of dollar deposits in Argentine accounts.
} 
Perhaps it is the lower inflation rate which has been observed since the 1990s. Despite all the talk of ratchet effects, disinflation certainly does seem to have the potential to lower dollarization ratios. This appears to have been the case in Lao PDR which had the sharpest decline in dollarization soon after the stabilization of 3-digit inflation in 1998-9. Earlier episodes of disinflation from high levels, as in Egypt and in certain East European countries, were also accompanied by a fall in dollarization ratios. Although current and recent inflation does not enter in a statistically significant way in the estimated regression equations, it would not be surprising if such an effect were masked in the analysis by cross-country variations in the size and timing of the response to inflation. It is less clear why the inflationary downturn should have had a sudden effect in 2002.

Local interest rates might also capture changing confidence effects regarding future inflation and exchange rates. Although these too do not enter strongly in the equations, this may reflect the general difficulty of modeling short-term confidence effects. As an instance of this difficulty, consider the experience of many Transition economies which were simultaneously working through the inflationary - and dollarization - implications of price liberalization while also starting to build the institutions that would stabilize their macroeconomies (including, for example, central bank independence).

Dollarization net of depreciation impact

Mean of balanced sample (76 countries)

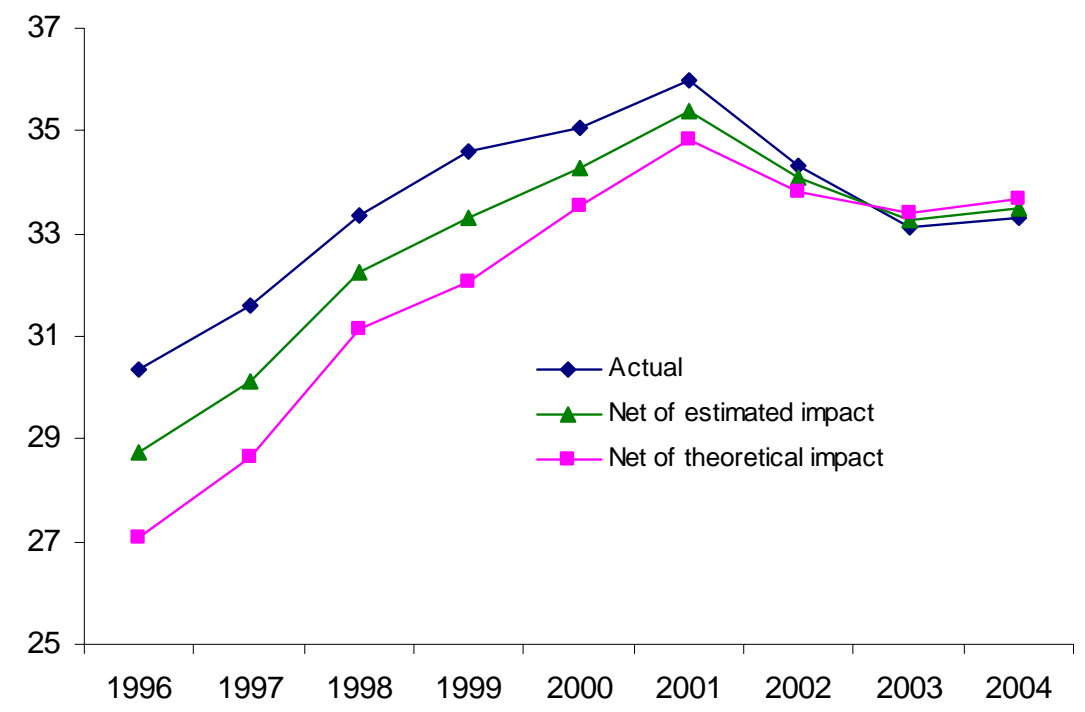

Figure 8 Adjusted dollarization figures showing underlying trend (a) 76 country mean

Even if these calculations serve to qualify the degree to which growth in dollarization shares has been reversed, they do not alter the fact that there has break in trend. Will 2001 be seen as a high point of dollarization, or have the last few years merely been a pause in what had been an inexorable worldwide trend? 
We cannot yet offer a conclusive answer to this question. The time trend remains significant in the dynamic equations that we have estimated, but it presumably summarizes the net effect of changes over time in underlying determinants including the institutional and macro-policy related variables discussed in Section 1 above. During the 1990s, falling inflation and some improvements in institutions coincided with growing dollarization shares. So, other factors acting to increase dollarization must have outweighed these identified elements. Globalization of trade and financial links is a plausible candidate. Efforts to identify such a link in cross-sectional regressions by including measures such as the share of international trade in GDP have not generally been successful, so this remains an unquantified though plausible hypothesis. If true, it would imply that growth in dollarization shares could continue provided that globalization deepens further.

But if such a process were to swell the number of high-dollarization countries, this would represent a departure from the pattern observed today, whereby each such countries is either an international financial center, or inherits a high inflation legacy, or is on the fringes of the euro-zone. If that pattern persists, then there will be few new highdollarization countries. Time will tell. 


\section{Consequences of high dollarization when exchange rates collapse}

Even if moderate changes in exchange rates do not trigger destabilizing movements in dollarization, it is clear that actual or expected exchange rate fluctuations in conditions of high dollarization can have a variety of severe effects.

First is the potential for a solvency impact. Indebted firms, financial or otherwise, which have unhedged portfolios in the face of such fluctuations risk insolvency. At first sight, it might be thought that this is just one more risk among many business risks facing firms in the modern world. Foreign-currency is just another asset to be added to the many being juggled by firms. However, because nominal exchange rates may have no anchor, fluctuations in nominal rates can be very large. Furthermore, foreign exchange risk in a highly dollarized economy is not something that can be diversified: it represents systemic risk. Finally, for banks in particular the risk of unhedged foreign currency risk can be large relative to their capital.

We note for completeness the well-known consideration that a foreign-currency denominated loan to a borrower whose business and receivables entails heightened credit risk correlated with exchange rates and therefore is a very imperfect hedge for foreign currency liabilities. It is for this reason that banks in many countries choose to use a sizable part of their foreign currency resources to buy lower-yielding foreign investments rather than lending to local borrowers in foreign currency. Honohan and Shi (2002) estimated that on average one half of foreign currency deposits are placed abroad.

It is not only through the local banking system that unhedged foreign currency liabilities can arise. In Indonesia, deposit dollarization was only around 20 percent before the crisis of 1997-8. Yet the solvency of banks was severely tested not least by the fact that some of their borrowers had contracted offshore loans denominated in foreign currency.

The second risk relates to the lender of last resort function, which is lacking in respect of foreign-currency denominated deposit liabilities (Fischer, 2000). Because of this lack, even if banks are adequately hedged against currency and credit risk, they may succumb to a form of liquidity risk in the event of a sudden shift of depositor preferences to foreign currency. If unable to convert sufficient local currency liquid assets into foreign exchange when such a depositor shift occurs, banks can suddenly become unhedged at the very moment when a currency begins to slide. Something like this happened in dramatic manner in Argentina 1989, and the authorities attempt at indemnifying the banks against the resulting foreign exchange losses fuelled a currency collapse in a cumulative destabilizing process. Ultimately, this event resulted in a depositor freeze, as did the later, somewhat different Argentine crisis of 2001-02.

Depositor freezes and forced conversion of foreign currency deposits (typically at offmarket prices) have occurred as part of the denouement of currency and banking crises in dollarized economies. The risk of such suspensions can be expected to be factored into bank interest rates. Indeed, the risk that the national authorities will suspend means that foreign currency denominated deposits carry a country-specific political risk premium. 
Some depositors may consider that they will have early warning of a suspension and choose to earn the risk premium as a form of carry trade.

The interest premium on hyphenated dollars varies within each country over time and very considerably as between different countries. Interest rate data is not as plentiful as that on the volume of dollar deposits, but there is sufficient to allow some general statements. Interest premiums have declined on average, but in every year since 1990 there has been at least one country with an interest premium in excess of 800 basis points. At 2004, interest rates reported to IFS on US dollar deposits ranged from 0.25 percent per annum (Argentina) to 8.71 percent (Azerbaijan) (at a time when onshore US CDs were yielding 1.5 percent). ${ }^{12}$ Figure 9 suggests a small positive correlation between dollarization rates and the USD deposit interest rate at that date.

Dollarization and USD deposit interest rate, 2004

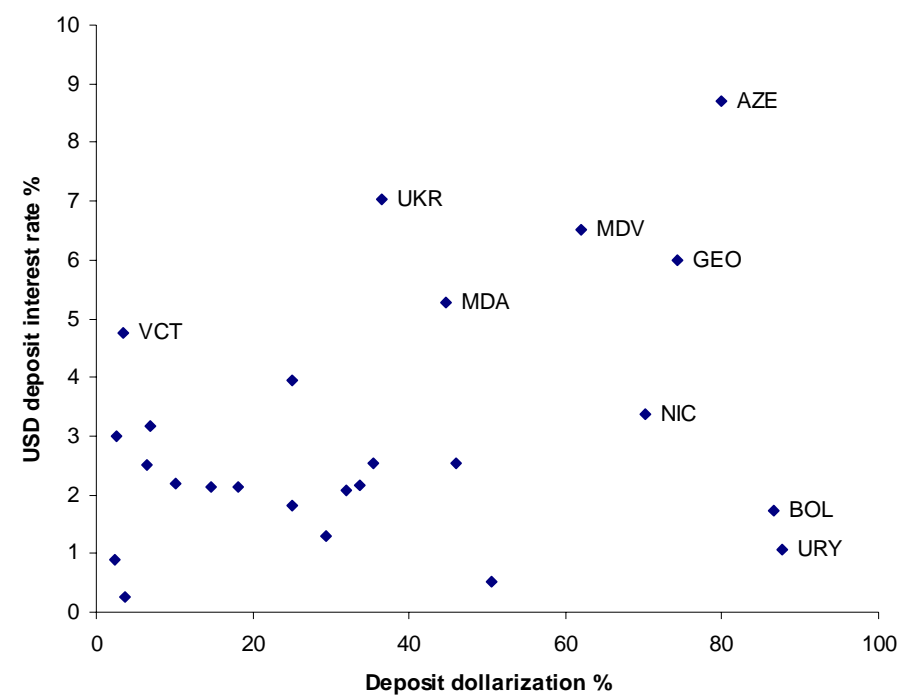

Figure 9: Dollarization rates and USD deposit interest rates, 2004 Source: Dollarization rates as in note to Fig 3; interest rates IFS line 60L.F.

Modelling determination of national interest rates in such different countries over a long time period is an elaborate exercise which is not attempted here (cf. Honohan, 2001). However, simple regressions (with autoregressive disturbance) on the data pool of some 1300 observations do suggest that higher dollarization is associated with higher interest rates and higher spreads. Table 3 summarizes the results of these regressions. When dollarization share was included alone the equations displayed severe autocorrelation, hence the inclusion of first and second-order autoregressive parameters. Their inclusion reduced the size of the coefficient on dollarization share and sometimes made it insignificant. However, whenever significant, the coefficient is always positive. ${ }^{13}$

\footnotetext{
${ }^{12}$ Lower than onshore US rates in some countries can result from the effects of exchange controls. Additionally, the comparability of the terms and conditions for the reported rates may differ from country to country.

${ }^{13}$ Inclusion of country fixed effects tends to eliminate significance of dollarization or reverse the sign.
} 
Table 3: Summary of regressions linking interest rates to dollarization shares

\begin{tabular}{|c|c|c|c|c|c|c|c|}
\hline \multirow[b]{2}{*}{ Dependent variable } & \multicolumn{3}{|c|}{ Dollarization share (no lag) } & \multicolumn{3}{|c|}{ Dollarization share (lagged once) } & \multirow{2}{*}{$\begin{array}{l}\text { NObs } \\
\text { (max) }\end{array}$} \\
\hline & & $\begin{array}{c}\text { with } \\
\text { AR(1) }\end{array}$ & $\begin{array}{c}\text { with } \\
\text { AR(2) }\end{array}$ & & $\begin{array}{c}\text { with } \\
\text { AR(1) }\end{array}$ & $\begin{array}{c}\text { with } \\
\operatorname{AR}(2)\end{array}$ & \\
\hline Lending - Deposit (spread) & $0.19 * *$ & $0.12 * *$ & $0.13 * *$ & $0.15^{* *}$ & $0.11^{* *}$ & $0.09 * *$ & 1240 \\
\hline Lending & $0.33^{* *}$ & $0.23 * *$ & $0.19^{* *}$ & $0.24 * *$ & $0.13^{* *}$ & $0.08^{*}$ & 1259 \\
\hline Deposit & $0.15 * *$ & $0.10^{* *}$ & $0.09 * *$ & $0.09 * *$ & 0.01 & 0.00 & 1307 \\
\hline Wholesale & $0.20 * *$ & $0.19^{* *}$ & $0.21 * *$ & $0.15^{* *}$ & 0.01 & -0.04 & 988 \\
\hline Lending: Local - USD & $0.17 * *$ & 0.12 & 0.04 & $0.12 *$ & -0.07 & -0.02 & 162 \\
\hline Deposit: Local - USD & $0.08 * *$ & 0.02 & -0.02 & $0.07 * *$ & 0.04 & 0.04 & 198 \\
\hline Lending - Deposit USD (spread) & $0.07 * *$ & $0.10^{* *}$ & $0.10^{* *}$ & $0.08 * *$ & $0.10^{* *}$ & $0.08^{* *}$ & 154 \\
\hline Deposit USD - Onshore US & $0.03 * *$ & $0.04 * *$ & $0.04 * *$ & $0.03 * *$ & $0.03 * *$ & $0.02 \dagger$ & 172 \\
\hline
\end{tabular}

Note: Each regression is of the form $i_{t}=a_{0}+a_{1} \delta_{t[-1]}+\varepsilon_{t}$, where $\delta$ is the percentage dollarization share discussed in text. The table entries show the estimates of $a_{1}$. In the second [and third] columns the error term $\varepsilon_{t}$ is modeled as $\varepsilon_{t}=\rho_{1} \varepsilon_{t-1}\left[+\rho_{2} \varepsilon_{t-2}\right]+u_{t}$. Estimation is by EViews.

Lending and deposit rates are IFS lines 60P and 60L; Wholesale rate is the maximum of lines $60 \mathrm{~B}$ and $60 \mathrm{C}$; USD rates are lines 60P.F and 60L.F; Onshore US rate is 11160LC. Data is for all available countries (up to 126) was used. NObs is the maximum no. of observations (inclusion of autoregressive parameters reduces available observations). ${ }^{* *}$ and $*$ denote coefficients significant at $1 \%$ and $5 \%$ levels respectively; that marked $\dagger$ has a $p$-value of 6.4 percent.

The point estimate for the equations where dollarization is entered with a lag imply, for example, that a 10 percentage point increase in dollarization is associated on average with between 90 and 150 basis points widening of the local currency intermediation spread; perhaps with a 90 basis point increase in the local currency deposit rate and, most interesting in the present context, with a 20-30 basis point widening of the spread of US dollar-denominated deposit rates in local banks over the New York CD rate. The more dollarization, the less secure the foreign currency deposits will be against suspension or other political risk, given that high dollarization could trigger a liquidity or banking crisis, likely to be associated with an exchange rate crisis. ${ }^{14}$

Thus, even if modest exchange rate fluctuations do not trigger sharp increases in dollarization, on the other hand high dollarization is associated with fear of future depreciation, and perhaps of a general currency and banking meltdown. These fears translate into the interest differentials which we have documented. They reflect social costs of the policies that result in high dollarization and in the interest spreads. That is not to say that dollarization is the only causal factor- to an extent (as has been shown above), dollarization itself reflects and concentrates other policy weaknesses. While the specific threats to financial stability can be addressed through prudential policy, action to correct the underlying weaknesses will be of broader and more lasting value.

\footnotetext{
${ }^{14}$ It is not hard to rationalize the other coefficients either. For example, the more dollarization, the less local currency funds are available for lending hence local currency intermediation spreads widen.

However, it will be clear that both dollarization and the interest rates are endogenous in a larger system that would need to be more completely specified - and estimated with the use of adequate instruments - in order to track the interrelations and paths of causality. A full discussion is beyond the scope of the present paper.
} 


\section{Concluding remarks}

Increasingly widespread growth in the use of foreign currency deposits in most countries around the world has complicated banking practice and supervisory concerns. This trend has also had an impact on exchange rate policy. While driven by a desire on the part of firms and individuals to hedge inflation and exchange rate risks, it may have increased systemic risks and the vulnerability of individual banks. We have shown that higher interest rates and interest rate spreads, reflecting fears of depreciation and suspension, are statistically associated with high dollarization.

This paper has concentrated on the two-way link between exchange rate movements and dollarization. Exchange rate movements (the surge and subsequent weakness in the US dollar) and regime changes (the arrival of the euro) have complicated the analysis of global dollarization trends. Our analysis, having disentangled these factors, suggests that, though underlying dollarization shares may not have fallen back, there has been a break in trend. Dollarization is here to stay. But, while there is still probably an underlying upward momentum in deposit dollarization that will continue to present policy challenges, the growth is likely to be slower than in the 1990s.

Specific policy addressing the consequences of dollarization itself, including steps to ensure that the credit and market risks, including the systemic risks are adequately internalized in the prudential management of intermediaries and their customers, represent one level of the needed response. ${ }^{15}$ But, to the extent that high levels of dollarization have their roots in volatile macro policy and weak institutions, more lasting and more effective cures will address these underlying causes.

On the other hand, policymakers should not overreact. Fearful that exchange rate movements might destabilize monetary holdings in an environment of deposit dollarization, some may have succumbed to a "fear of floating." But our econometric results suggest that such fears can be exaggerated. ${ }^{16}$ Exchange rate movements do not, on average, result in extrapolative destabilizing re-denomination of the currency of deposits. While dollarization shares are impacted by exchange rate changes, even the mechanical exchange rate impact is on average partly rebalanced within the year.

Indeed, if fear of floating is carried to the point of persisting with a fixed exchange rate that has become seriously out of line with fundamentals, the eventual large exchange rate adjustment which may be forced on the authorities could, with a highly dollarized banking system, have severe solvency effects both on unhedged borrowers and on their creditor financial institutions.

\footnotetext{
${ }^{15}$ Media reports suggest, for example, that even in Hungary and the Baltic States, where (as documented in the European Central Bank's June 2006 Financial Stability Report) foreign currency-denominated lending ranges from about 45 percent (Hungary) to the range 60-75 percent of total bank lending (Baltics), many borrowers, especially mortgage borrowers, do not adequately understand the currency risks they have assumed.

${ }^{16}$ This is not to deny that exchange rate depreciation can lead to financial sector problems where firms have net foreign exchange exposure.
} 


\section{References}

Arteta, Carlos O., 2002. "Exchange Rate Regimes and Financial Dollarization: Does Flexibility Reduce Bank Currency Mismatches?” International Finance Discussion Paper 738, Board of Governors of the Federal Reserve System, September.

Arteta, Carlos O., 2003. "Are Financially Dollarized Countries More Prone to Costly Crises?" International Finance Discussion Paper 763, Board of Governors of the Federal Reserve System, March.

Baliño, Tomas, Adam Bennet, and Eduardo Borensztein, 1999. "Monetary Policy in Dollarized Economies," IMF Occasional Paper 171.

Calvo, Guillermo and Carmen Reinhart, 2002. "Fear of Floating," Quarterly Journal of Economics 117 (2, May): 379-408.

De la Torre, Augusto and Sergio Schmukler, 2004. "Coping with Risk through Mismatches: Domestic and International Financial Contracts for Emerging Economies," World Bank Policy Research Working Paper 3212.

De Nicoló, Gianni, Patrick Honohan and Alain Ize, 2005. "Dollarization of the Banking System: Good or Bad?" Journal of Banking and Finance 29(7): 1697-1727.

Fischer, Stanley. 2000. "On the Need for an International Lender of Last Resort," Essays in International Economics, Department of Economics, Princeton University, No. 220.

Goldstein, Morris and Philip Turner, 2004. Controlling Currency Mismatches in Emerging Economies, Washington DC: Institute for International Economics.

Honohan, Patrick, 2001. "How Interest Rates Changed under Liberalization: A Statistical Review," in G. Caprio, P. Honohan and J.E. Stiglitz, eds., Financial Liberalization: How Far, How Fast? New York: Cambridge University Press.

Honohan, Patrick and Anqing Shi, 2003. "Deposit Dollarization and the Financial Sector in Emerging Economies," in J. Hanson, P. Honohan and G. Majnoni, eds. Globalization and National Financial Systems, New York: Oxford University Press.

Ize, Alain and Eduardo Levy Yeyati, 2003. "Financial Dollarization," Journal of International Economics, 59: 323-347.

Kaufman, Dani, Aart Kraay, and Massimo Mastruzzi, 2006. "Governance Matters V: Aggregate and Individual Governance Indicators for 1996 - 2005," World Bank Policy Research Paper 4012.

La Porta, Rafael, Florencio López-de-Silanes, Andrei Shleifer, and Robert W. Vishny, 1997.

"Legal Determinants of External Finance," The Journal of Finance 52(3):1131-50.

Levine, Ross, Norman Loayza, and Thorsten Beck, 2000. "Financial Intermediation and Growth: Causality and Causes," Journal of Monetary Economics 46(1):31-77.

Levy-Yeyati, Eduardo. 2006. "Financial Dollarization: Evaluating the Consequences," Economic Policy 45: 63-118. http://200.32.4.58/ ely/papers.html 